\title{
Consumerism, the Nigeria Experience: Study of the Food and Drink Industries 1980-2012
}

\author{
A. E. Ndu Oko \\ Senior Lecturer of Marketing \\ Abia State University, Uturu, Nigeria \\ E-mail: a.e_nduoko@yahoo.com
}

Osuagwu Linus

Professor of Marketing

School of Business \& Entrepreneurship

American University of Nigeria, Yola, Adamawa State, Nigeria

$\begin{array}{lc}\text { Received: June 19, } 2013 & \text { Accepted: August 1, } 2013 \quad \text { Published: August 23, } 2013 \\ \text { doi:10.5296/bmh.v1i2.4162 } & \text { URL: http://dx.doi.org/10.5296/bmh.v1i2.4162 }\end{array}$

\begin{abstract}
The work is an evaluation of consumerism activities in Nigeria with specific interest in the food and drink industries. It considered the growth and challenges to consumerism, the impact of the non-active nature of consumerism on the health and environmental standard of the country. Data generated based on the use of sets questionnaire were analyzed using analysis of variance statistical tool. Findings include that the inactive nature of consumerism in Nigeria contributes significantly to the exploitative attitude of manufacturers, explicitly through high price of products and implicitly by the debasement of the environment through improper management of residues (waste), resulting to poor health and environmental standard. Solution among others is that firms by suasion should be encouraged to adopt marketing concept philosophies, principles, policies and strategies for the maximization of corporate goal, consumer welfare (satisfaction) and macro economic development of the society.
\end{abstract}

Keywords: Impoverished economic state, sub-standard quality, consumerism, poor environmental standard, consumer sovereignty, marketing concept, environmental protection $\operatorname{tax}$ 


\section{Introduction}

Globally, consumers and consumer protection agencies are increasingly becoming concerned over air, water and ground pollution and are designing laws and increasing power and rights of institutions charged with the responsibility of consumer protection and its extension-environmental protection.

In the USA are laws on issues relating to competition, product safety and liability, fair trade and credit practices, and packaging and labeling - Cohen (1995). In the bid to ensuring consumer protection, Norway bans several forms of sales promotion, among which are contests, premiums, as inappropriate or unfair instruments for promoting products, as well as trading stamp. In Thailand, low priced products are marketed along side high priced products of same brand as a means of protecting the interest of low income earners and in India, special approvals are required to proliferate already existing market offers for horizontal and or vertical market expansion-Kotler and Keller (2009:126). They are other such laws as the clean air Act of 1990, protecting the environment against acid rain and air pollution; the telephone consumer protection Act of 1991, that addresses issues concerned with telemarketing abuses, and the children's online privacy protection Act of 1998, which requires the permission of parents before collecting personal information from minors-Heckman (1999).

Given this wave of consumer protection, demands for ecologically safe products and ethical and socially responsible business practices are on the increase.

This work is aimed at assessing the degree of responsiveness of firms and governments to consumerism/consumer group operating in the food and drink industries in Nigeria with particular reference to the management of residues (waste) as environmental pollutants.

\section{Theoretical Frame Work}

Businesses exist to satisfy the interests of its owners, as shareholders, the management, employees and the consumers-Okeke (1981). These interests when unbalanced in satisfaction create disharmony; which is worst with neglect of the consumers.

In Nigeria, the interests of consumers have often been relegated to the background especially in the food and drink industries as these businesses exploit different target markets in their desire to actualize excess profit objective. The fight against this, - exploitation-is the hub of consumerism.

Consumerisms as noted by authorities in marketing in Nigeria have since the 1970's remained inactive - Onah (1979), Agbonifoh, Ogwo, Nnolim and Nkamnebe (2007) and Ayozie (2013), given the absence of enabling operational environments, hence the plights of consumers have not received adequate attention.

Consumerism in most developing and developed economies thrives based on collective activities of government, organizations/ associations, journalist exposes and individual consumers-unesco-nigeriatve.org/teaching\%20materials/ltm/.../week12.html. In Nigeria government has always played the role of OMBUDSMAN supported by little journalistic 
exposes. Organisations/associations and individual consumers activities are relatively non existence. This reasonably accounts for the poor development of consumerism, organizations and associations as cited by Ayozie (2013). Literature on consumerism are those of the 1979-1980, especially activities credited to the tenants association, the consumers associations in Lagos, Aba, Kaduna and Onitsha, the Enugu consumer movement, the consumer club of Awgu among others are those of 1986-88 as cited by Onah (1997).

Ayozie (2013) asserts that consumerism is on the increase in Nigeria based on increase in level of education and standard of living, hence awareness of consumer rights is on the increase as well as fight against exploitation. It is disheartening to state that apart from the referred to cases of Phizer Pharmaceutical in Kano and Kaduna states and my pickin product in Lagos, no other cases of consumer right abuse is on records in Nigeria except those listed on Okeke (1991) as reported between 1986 and 1988 - see Ogwo (1991).

The prompted increase in consumerism activities in Nigeria in the opinion of Ayozie (2013) is also attributed to the roles NDIC, AMCON, SERVICOM, NAFDAC, CBN and Consumer Protection Council of Nigeria. These organizations exist and function in part as government's OMBUDSMAN. This supports Halliru's (2012), assertion; that consumerism in Nigeria is more in the form of government legislation and enforcement than organized consumer associations. It is also observed that these agencies except a few, perform below expectations as the awareness of their existence among Nigerians is equally low-Halliru (2012). The statement credited to Ayozie (2013) thus: “Today's consumer is better educated than his forebears and thus less unwilling to accept the exaggerated salesmanship and misleading advertisements, shoddy goods and even deceit that buyers once considered the natural hazards of commerce" is but an over assessment of the Nigerian situation as it contradicts - Ayozie (2013) who also stated that "Today there are more fake drugs than ever before in the country while quacks and opportunists dominate the dispensing and sales of drugs".

This work rather pitches tent that-Halliru (2012) and naturalnigeia.com (2012), that majority of Nigerians though quantitatively educated are qualitatively ignorant and with etukudo (2008), that asserts that the marketers as producers and vendors have employed aggressive methods, strategies, and media to influence consumer opinion, attitude and actions, thus consumers are mislead into wasteful expenditures. This accounts for why Nigerians spend as much as $\$ 110,000.00$ ( $\$ 695$ ) on a single mobile phone that is replaced within one year of usage, so much on cars and rentals on residual apartments and women wear weaves that cost $\$ 150,000.00$ and above in average, while children and adults carry about expensive ipads and other electronic gadgets - natural nigerian.com/2012.

The media in collaboration with vendors, given the growth in quantitative rather than qualitative education based on the use of information technology system are guiding consumers into making unintelligent and non-beneficial purchase decisions, thus unsafe as well as low quality market offers whose usages result to human and environmental health abuse are patronized even at exorbitant prices - etukudo (2008).

Consumerism as practiced in other nations (developing and developed) has the tendency of 
improving the welfare of the different targets of defined and specified marketing efforts. The situation in Nigeria is a negation of standards. Assessing consumerism in Nigeria based on Kaynak's (1982). Consumerism Life Cycle (CLC) model with its four stages of crystallization, organization, institutionalization and conceptualization, and special highlights or bases of stage identification as value and volume of information available to consumers, operational efficiency of consumer protective legislations, government consumer OMBUDSMAN agencies, willingness and ability of different publics to finance consumer education and protection activities and degree and level of awareness and sensitivity the masses and specific markets by segmentation have towards market force manipulation and protection. Nigeria consumerism activities and success rate are best classified as those of the primary state (stage) of crystallization.

This classification is supported by Halliru's (2012) assertion, that consumerism in Nigeria is dominated by government agency activities with little or nothing from the organized private sector as individuals and or artificial persons.

The question that calls for attention is why Nigeria has remained at the primary stage of consumerism development for over 40 years of the existence of this course for consumer protection.

Currently, evidences show that corporate neglect has been extended beyond poor quality of core products; inadequate consumer education and information; poor or absence of after sales service delivery among others to the exploitation of the consumers' (current and potential) physical environment, as the major and minor streets of urban and sub-urban areas are littered with residues (wastes) that result from industrial operations and domestic consumption of the products of firms. Consequently, the health standard of the general public is under serious threat.

The fight against this environmental mess through withdrawal of patronage by consumers - Okpara (2002), is considered ineffective based on the absence of alternative offer resulting from the absence of competition among firms in the industries,' excess of demand for market offer over supply and the attendant political and economic power which these corporate bodies have always used to enact laws to protect their interests (Akerele 1980) or to thwart existing laws.

This work thus sees the consumers and consumerism as powerless in the Nigeria context, thus it is interested in solution to the plights of the Nigeria consumers.

\section{Objectives of the Study}

This research is interested in achieving the following:

- To establish the fairness or otherwise of price differences between different package forms of the same product (in quality and quantity), marketed based on uniform blending of the promotion and distribution tools of marketing;

- To determine the fairness or otherwise of the high cost of products with disposable package compared to those whose packages are subject to reuse through recycling; 
- To determine the reasonability or otherwise, the expectations of producers, that consumers, after haven paid high price for disposable packaged products, to be responsible for the management of the residues (wastes) products as empty packages;

- To determine whether or not the producers in Nigeria especially in the food and drink industries are exploiting the consumers, debasing the environment and are de-marketing based on principles and practices, thus are not socially responsible and nor consumer oriented in policies and philosophies;

- Finally, the work is aimed at determining the challenges to the practices of consumerism on Nigeria with particular reference to the food and drink industries with a view to proffering solution.

\section{Significance of the Work}

The existence of production activities is made relevant by the consumption of the outputs of production exercise; hence both compliment one another for the economic development of states. It is on this note that this work is considered significant, as it offers solution to the constraints common to the protection of consumers rights to fairless in production and exchange relationships.

It highlights and exposes the continued consumer dissatisfaction with business performances given the inability and unwillingness of businesses to be marketing concept oriented in philosophies, policies and strategies.

Recommendations to this exercise are capable for spurring revival in government attitude to consumerism as compliment and or supplement to private sector initiatives on consumer protection in Nigeria.

\section{Hypothesis}

This research is anchored on a single hypothesis stated in null form thus:

H0: Poor (inactive) state of consumerism activities in Nigeria does not significantly impact on the health and environmental standard of Nigeria.

\section{Literature Relevant to the Study}

In every economic society where exchange and transaction take place, basic conditions of the existence of at least two parties with ability, willingness and qualification to enter into relationship, having items for exchange and ability to communicate offer must exist-Agbonifoh, Ogwo, Nnolim and Nkamnebe (2007) and Ayozie (2013). Thus there must be the buyers and the sellers, who have rights in the exchange relationship.

Traditionally, the rights of sellers in exchange and transaction relationships include:

- The right to introduce any product in any size and style, provided it is not hazardous to the personal health or safety; or, if it is, to include proper warning and controls; 


\section{Macrothink}

Business and Management Horizons

ISSN 2326-0297

2013, Vol. 1, No. 2

- The right to charge any price for the product, provided no discrimination exist among similar kinds of buyers;

- The right to spend any amount to promote the product, provided it is not defined as unfair competition;

- The right to use any product message, provided it is not misleading or dishonest in content or execution; and

- The right to use any buying incentive programmes, provided they are not unfair or misleading.

While the buyers' rights include

- The right to buy a product that is offered for sale;

- The right to expect the product to be safe; and

- The right to expect the product to perform as claimed-Kotler and Armstrong (2006:633).

Evaluating these sets of rights on comparative basis, the in-balance is often in favour of the sellers, especially in the developing economy where the level of inter and intra industrial competition is low, the level of consumer awareness and education is low and level of per capita income disparity between the few rich and mass poor of the populace of the society is high.

To ensure the actualization of the objective of protection for the consumers in the face of impoverished economic state, demands fortification of the rights of buyers to include

- The right to be well informed about important aspects of the product;

- The right to be protected against questionable products and marketing practices; and

- The right to influence products and marketing practices in ways that will improve the quality of life.

Records available show that inspite of these rights as fundamental to good marketing practices; consumers are continually being exploited in Nigeria.

\subsection{Need for Revived Consumer Protection Activities in Nigeria}

The Nigeria market force as demand is weak compared to supply. This weakness is evidenced given sharp practices of vendors in the areas of deceptive advertising, high pressure selling, shoddy and unsafe products, planned obsolescence and arbitrary price adjustment is favour of vendors - etukudo (2008) and Agbonifoh, Ogwo, Nnolim and Nkamnebe (2009). Based on the above, consumers are not only hapless - Adewakun and Sheu (2013), but hopeless and helpless-Ayozie (2013), especially following constant vagaries in government policies and decisions that have reduced the purchasing power of consumers, and eliminated the middle income earning class. 
The situation in Nigeria, given the elimination of the middle income earning class has created large gap between the rich and the poor thus over 85 percent of the populace are economically disenfranchised, thus cannot select from a range of products (goods and services) offered at competitive prices with a hope of deriving satisfaction-Adewakun and Shue (2013). This is in the face of higher expectation of better lifestyle caused by increase in net income rather than real income and sociological changes-Haliru (2013), occasioned by media driven class aspirations and exaggerated class consciousness — naturalnigeria.com/2012.

The market has great influx of poor, fake and sub-standard products, especially in the absence of competition in most industries that leaves the consumers without alternatives. These consumers, majority of whom are low income earners do not often seek redress for violation of their rights to fair dealings in their exchange relationships with vendors owning largely to their sense of poverty occasioned by high level of ignorance-Adewakun and Shue (2013), thus; they have always depended on government for protection.

Advocates for consumers protection based on government regulations are of the opinion that regulatory agencies given intensified efforts can get rid of the nation's markets of adulterated goods as a means of ensuring non violation of consumers rights-Adewakun and Shue (2013). This is however an uphill task without direct involvement of the consumers as individuals, organized natural and or artificial persons. Getting Nigerian consumers directly involved in consumerism is only possible given quality consumer education, not only for the poor but also for the rich.

\subsection{Consumer Exploitations in Nigeria}

Consumers expect value-satisfaction for every exchange relationship; hence business organizations owe it as duty to care for customers in all their manufacturing and selling efforts. Commonly recorded in most exchange relationships is dissatisfaction, hence the rise of defensive consumerism-Olusaga (1978). The dissatisfaction of consumers arises and manifests thus-Okeke (1991:12)

- Misleading and often false consumer education largely carried on by businesses through corporate and product advertisements;

- Short changing of consumers through substandard quality and inadequate quantity of product offerings;

- Outright sales of injurious products and services to consumers; and

- Concerted and ingenious manipulation of product prices that force consumers to pay more to get even less value.

Common accounts of exploitative business practices and consumer dissatisfaction in Nigeria include:

- Proliferation of adulterated and fake products especially pharmaceuticals in the Nigerian markets. Records have it that as far back as 1988 , more than $50 \%$ of drugs in the 
Nigerian markets were fake or adulterated-Igboaka (1998:11). It is pertinent to record that the situation is worse contemporarily compared to 1988 as many of the imported drugs (chloroquine) in circulation in Nigeria are and were substandard, containing more explicients than active ingredients-Orere (1988:3). In 2002, the World Health Organization reported that 70 percent of the drugs in Nigeria were fake or sub-standard, in 2004 the figure was $48 \%$, as most of the anti-malaria drugs were fake (htt.//wwwkereatimes.co.kr/www/news/opinon/2008/01/137.16571.html.and Roger (2009:1)). The situation is so bad that the National Agency for Food and Drug Administration and Control has continued to cease and burn sub-standard consumers products especially drugs and cosmetics worth millions of Naira in Aba, Onitsha, Lagos and Jos (www.nafdacnigeria.gov.ng);

- In the practice of medicine, records abound of proven cases of professional negligence as some medical practitioners are accused of insensitivity to the wellbeing of consumers (patents) of their services Adinoyi-Ojo, Seun, Ogbeide and Anukwe (1988);

- In the electricity and power sector, consumers of electricity are billed for energy they did not consume nor were supplied. Failure to make such payment as demanded is met with "dis-connection" from supply points. Case in point is the reported mis-understanding between the Sokoto State Government and the Power Holding Company of Nigeria—over non supply of electricity-;

- Cases are also reported in the pharmaceutical industry in Kano and Kaduna states concerning Phizer Pharmaceuticals and that of my pickin product in Lagos-Ayozie (2013);

- The communication industry contemporarily like in the past has not led up to expectation of consumers. In the era of NITEL, residents of Victoria Island Lagos were forced to accept the IDD system-Oghume, Arinze and Mba (1988);

- Currently the major Network service providers in the communication industry in a bid to expanding and consolidating market share have introduced different forms of (bonus) incentives-(sales promotion activities) and have allowed their platform to be used for various advertisements that intrude into service consumers privacy. 


\section{MInstitute ${ }_{\text {Macrothink }}$}

These include:

5471880390

When ever you are free then call me on 54718803090

\author{
Received: \\ 06: 38 : $15 \mathrm{am}$ \\ 28-03-2013
}

From 33180

Be the list to apply for that dream job with your Phone! Get newest job openings \& send your CV Immediately with Glomobilecv. To subscribe, send Sub to 33180

Received:

09: 59: 41.am

$19=03=2013$

From

(No Name)

33180.

\section{7}

Excellent! 08057851630 is among the favorites who has the privilege to get 7 free daily history SMS by infobox and then $\$ 100$ /week! Text Go to 30807 for free!

Received:

09: 42: 11am

22-03-2013

(No Name)

30807

30800

This Easter wish your friends and family a special greeting card to show your love and affection, simply send $<$ your name $>$ to 30800 to create the card. Once the card is created, you Will receive a SMS from 30800 , which you can just forward to and sweetly surprise your friend.

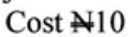

Received:

04: 10:12pm

26-03-2013

From 32929

find out what's happening in sports from La-liga Champions league, Europe league and EPL! Get Exciting updates from ESPN NOW!

T \& ESPN to 32921 free till Mar 21.

"I am Shade, 23 years of Age, slim and tall, can we be friends"

There are also common cases of network futures; call drops and termination of calls for reasons of inadequate credit balance. Nigerian Telecommunication services users as consumers have always remained helpless in the hands of these Network service providers.

Businesses in Nigeria in this era of relationship marketing, as an off shot of marketing concept are still practicing based on product and production concepts, thus market offers as outputs do not meet consumers' specifications and requirements-Ekenma (1987:43). This shows that firms in Nigeria do not invest in marketing research as means of ascertaining what consumers needs (wants) before embarking on production. Price of goods as in the bottling industry-NBC Plc and 7Up Nig Plc is higher than the value of goods. This accounts for the banding of sales of NBC products at the University of Nigeria Enugu Campus between 2000 and 2002 by the Students Union Government. Currently in Nigeria, a bottle of 7Up and coke, products of 7Up bottling Company Plc and Nigeria Bottling Company Plc of 35cl are sold for $\$ 50.00$ and $\$ 60.00$ respectively while the aluminum and plastic canned (packaged) are sold for $\$ 100.00$ at $33 \mathrm{cl}$ at price differential of $\$ 50.00$ and $\$ 40.00$ respectively and $50 \mathrm{cl}$ of the product (plastic and aluminum packaged) is sold at $\$ 120.00$. Both the bottle packaged and aluminum can or plastic packaged products of these firms have the same quality ingredients. While the bottles as residues (wastes) are recycled for re-use based on reverse logistic 
management technique, the aluminum can and plastic containers litter the environment and block the drainage ways causing environmental nuisance and health hazards.

\subsection{Wave of Consumerism Activities in Nigeria}

Nigerian consumers are enjoying increase in the level of education and awareness as a result of government support for the media houses, knowledge of consumer right is in the increase like the rate of abuse of these rights, but in the present time, unlike the past Nigerians do not express dis-satisfaction in exchange relationships by instituting court actions against producers and marketers.

In 1986, Omotayo through his counsel instituted an action against Regolis, producer and marketer of pure natural water for breach of duty of care, demanding $\$ 50,000.00$ as special and general damages. The case was decided in favour of the plaintiff on the 28th May 1988 as Ragolis was found liable for generable damages for the breach of the duty of care-Oloke (1988:37).

Reported also is a case of breach of duty of care between Yemi Olukoya and Guinness Nigeria Plc, brewers of Harp Larger Beer-Otu (1988: 46-47). This was following the nervous shock, suffered by Yemi Olukoya given the notice of a strange object in a bottle of harp lager beer bought by plaintiff that caused Olukoya instant vomiting and emotional stress.

While the incidence of producers and marketers negligence (duty of care) is increasing, the number of reported and prosecuted cases is on the decline. The reasons for this decline in the number of prosecuted cases as consumerism activity is also subject of research investigation. However preliminary survey result shows that the process of seeking and obtaining redress in Nigeria is time consuming and cost involving hence; cases linger for onwards of twelve (12) years as producers (as defendants) often influence the process to their advantage, securing long term adjustments, as were the cases of Adetoun Oladeji (Nig) Ltd V. Nigerian Breweries Plc-Supreme Court No 91/2002-Nigeria Weekly Law Report April 2007 (5) and AC Leventis Nig. Plc V. Chief Christian Akpu-Supreme Court of Nigeria 140/2002-Nigeria Weekly Law Report December 2007(17).

Generally, it is an accepted assertion that consumer dis-satisfaction is a foundation of consumerism. This is however not sufficient for the development of consumerism activities where majority of the people lack better vision of their state of affairs and the prospects of attaining their vision and the inability to emerge a good quality leadership to give direction to the (consumer group) organization in a bid to actualizing consumerism objectives-Herrman (1970:55-56).

Supporting the above assertion, Onah (1979:32), opines that a good political system based on civilian democratic principles must exist in a state, in the presence of increasing level of good quality rather than quantitative education and perceived health and safety problems accompanying industrial reaction as pre-requisite for pushing people to activist consumerism.

Nigeria is operating democratic governance, however, the educational system is quantitative rather than qualitative and the greater number of the citizenry are yet to perceive the health 
and safety problems associated with industrialization activities of the food and drink industries, given the large number of aluminum cans and plastic packaging residues (wastes) that litter the environment.

Contributing to the discourse, Akerele (1980:50), opines that democratic system that institutionalizes a rigid social class structure in the society will accentuate the power equalization argument and make consumerism relevant. This situation is obtainable in Nigeria as power disparity exists between buyers and sellers in this imperfectly competitive system, yet consumerism is still at its lowest ebb of activities compared to any other developing nations of the world.

Preliminary research findings on the level of consumerism activities in Nigeria support the assertion of Gill (1973:592), that consumerism is threatened not only by the concentration of economic power in small number of firms as it is in the food and drink industries, but also by the failure in many cases of the so called regulatory commissions to do anything to improve the situation. Given this, this work evaluates the role of environmental protection agencies in Nigeria as well as the States and Federal Ministries of environment on the control of activities of the firms in the food and drink industries vis-à-vis the littering of the environment with residues (waste) in aluminum cans and plastic packages. It is however possible that the business and public sectors have merged in union of common goal, thus is the obvious greater danger of relying upon agencies of the government to curb the possible abuses of power by vested industrial interests - Gill (1973:592).

Primary research work on this discourse also shows that the differences in business and social-cultural philosophies across the major ethic groups in Nigeria accounts for the low level of consumerism activities. While the people of South West Nigeria will insist, demand for and resort to litigation for wrongs wrought on them by businesses, the Northerners and Easterners will consider litigation as waste of time and resources, thus will resort to informal complaints. This attitude of the Northerners and Easterners encourages unethical practices among business organizations, as such, Nigerian producers and marketers are more of imitators than innovators, hence their products are considered unsafe-Aire (1974:13-17). Products in goods and services in virtually all the sectors of the economy are considered to be of low quality-Aire (1974), Sanwo (1975) and Osunbor (1984). The situation is not better in respect to fake and imitative spirits, motorcycles and vehicle spare parts-Lawson (1977:24-34). Greater dis-service to the society is the practice of deceit based on the use of false labels for products purporting them to be foreign products-Edoreh (1984:31-36) and Olusoga (1978:295-303).

In the past as it is currently, the weaker market force (consumers) in Nigeria complain about mis-leading advertisements, high price of market offer, hoarding and the creation of artificial scarcity and a general absence of consumer orientation among Nigerian businesses - Edoreh (1984:30-36), Akerele (1980:44-51) and Ogbeide (1981) in Agbonifoh, Ogwo, Nnolim and Nkamnebe (2007:662). The situation in Nigeria based on these acts of deception is a serious disturbance of the faith of the consumers in the ability of the market force to exercise the desire protection-Edoreh (1984:30-36). 
On this account, this research is interested in establishing the reasons for the exploitation of the Nigerian markets by multi-national firms in the food and drink industries based on over pricing of the liquid content of their aluminum canned and plastic packaged products and the littering of the environment with residues (wastes), practices that are not obtainable in the developed and other developing nations of the world, and to proffer solution to this situation.

\subsection{Governments Participatory Role in Consumer Activities in Nigeria}

Authorities in marketing are of the opinion that discontentments with market offer are traced to such factors as incompetence, reluctance by vendors as marketers to resolve complaints especially in the absence of after sales services and government continued direct participation and domination of productive activities - Andreasen and Best (1977), as such, the force of regulation is weakened. Kaynak (1982), asserts that consumerism (OMBUDSMAN activities) of government is attributed to preponderance of violations of policies in the areas of distribution of products (goods and services) and general exploitation of consumers due to poor level of awareness and education. Given (these) above, the government of Nigeria in 1971 established the Standard Organization of Nigeria (SON) through an enabling Act Number 56 of December 1971 as amended in 1976, 1984 and 1990 based on Acts number 20, 32 and 18 of the respective years. This organisation by Act is empowered to regulate the standard of products meant for consumption in Nigeria-SON (2003); in 1992, the Consumer Protection Council was established with the mandate of removing and eliminating from the markets hazardous products; in 1993, the National Agency for Food and Drug Administration and Control was established under Decree N0. 15. This was spurred up by the request of World Health Organisation that member countries should join hands in combating the global threat to health, resulting from the increase in manufacture and distribution of fake, adulterated and counterfeit pharmaceuticals; 1992 saw the establishment of the Nigeria Communication Commission (NCC), under Decree Number 75 of November 24. This commission has the duty of regulating and creating enabling environment for operators in the telecommunication industry, especially infusing intra industrial competition that will ensure the protection of the interest of telecommunication service consumers.

It is unfortunate to report that these organizations, some which are/were military (Decree) regulatory organs have performed below expectation with however an exception-NAFDAC. Even at that, the activities of NAFDAC are centred on seizure and destruction of fake medications and closure of shops of fake drug manufacturing units-NAFDAC (2005). The activities of NAFDAC have been constrained by necessary but rigid judicial system in Nigeria as well as the non-committed attitude of staff of the organization especially as they collude with fake drug manufacturers-Halliru (2013) and Ayozie (2013).

In the telecommunication industry in Nigeria, performances of firms are poor, sequel to inadequate infrastructure, poor enabling environment and high cost of operation. However, the intra industrial competition based on the de-regulatory policies of government spurs firms to value delivery. It is believed that the firms in this industry will begin to create delight in consumers of their services through enhanced quality of offer.

Contemporarily (post military era) in Nigeria, other organizations and institutions such as 
Nigerian Deposit Insurance Company (NDIC), Assets Management Corporation of Nigeria (AMCON), Service Compact (SERVICOM), Economic and Financial Crimes Commission (EFCC), the Central Bank of Nigeria (CBN) among others exist to compliment government efforts at ensuring enhanced quality of goods and services to consumers. These organizations as managed and operated by Nigerians are inefficient and ineffective as they are ladened with corrupt practices. It is important to note that but for the de-regulation in the banking industry with its attendant intra industrial competition, the nation would still, have been experiencing the high incidence of bank failure and loss of stakeholders' investments and welfare, following corrupt practices. Competition in the industry has reduced the cost of capital and charges on services, thus has enhanced the welfare of service consumers through created delight.

\subsection{Nigerian Consumer-Attitudinal Framework}

The situation of the Nigeria consumers is poor, they may be no difference rather significant difference between the military and the post military era consumers in Nigeria, as national wealth is controlled by a few individuals. Poverty in Nigeria is traced to political issues, hence hunger and environmental degradation is high-www.globalissues.org (2013). Seeking redress for violation of consumers' right is constrained by poverty-Adewakun and Shue (2013). The last records of real consumer movements were those of 1986-1988 - Onah (1997). The few reported cases of consumer activities associated with increase in pump prices of petroleum products and the evidenced activities of Niger Delta oil militants-Ayozie (2013), were occasioned by oil cabals, interested in personal rather than the (system) macro economic growth and development of the economy through organized consumerism ventures., The idea of consumerism as a movement or a set of policies aimed at regulating the product, services, methods and standards of manufacturers, sellers, and advertisers in the interest of the buyers-consumerism.answers.com, is still in the early stage of development-Adewakun and Shue (2013) and Halliru (2013). It is thus imperative that business de-regulation policies in the absence of self-regulation by businesses must be put in place in Nigeria. Claim that organizations have recently started making attempts at ensuring the protection of consumers' right by improving communications with consumers and by developing programmes to educate consumers-thecontroller.blogspot.com (2008) is only in the de-regulated industries of banking and telecommunication.

The assertion that consumerism is growing in Nigeria is nothing but an overstatement-Adewakun and Shue (2013), as consumers are relatively uninformed, unguided, unintelligent in purchase decisions, unexposed to market offer alternatives, they are poor, but social class conscious, hence are not sophisiticated to contend with vendors who take advantage of their positions and resources to exploit consumers-thecontroltower blogsppt.com (2008), given their constant psychological and sociological change tendencies. Given this, consumerism must continue to express itself by way of government legislation and enforcement against organized public activities — Kaynak (1982).

\section{Methodology}

The activities of firms in the food and drink industries in respect to consumer welfares with 
bias for price and quality values equilibriums; management of residues (wastes) and consumer education were appraised and compared with world standards. Opinion of consumers through copies of questionnaire were sought to collaborate or otherwise information generated given interaction with manufacturers and marketing intermediaries. The Likert scale statistical tool was employed to determine significant factors that have constrained consumerism activities in Nigeria as well as those that have the ability of spurring up consumerism and oral interviews were used as supplementary source of data, given discussions with principal participants in the fights against consumers' rights abuse in Nigeria.

These respondents were carefully selected to show good representation of the markets (consumers) and vendors in the six-geo-geopolitical zones in Nigeria.

\section{Analysis}

Based on table 2, the hypothesis of this exercise is stated thus:

H0: $\quad\left(\mu_{1} \neq \mu_{2} \neq \mu_{3}\right)$ There is no significant difference between the rating of the three groups of respondents, on the impact poor consumerism activities on the health and wealth and environmental standard of Nigeria.

$\mathrm{H}_{1}:\left(\mu_{1}=\mu_{2}=\mu_{3}\right)$ Significant difference exists between the rating of the three groups of respondents on the impact of poor consumerism activities on the health and environmental standard of Nigeria.

Where: $\mu_{1}, \mu_{2}$ and $\mu_{3}$ are means of the rating of the three categories of respondents.

Given: $\quad \mathrm{f}=\underline{\mathrm{V}}_{\underline{\mathrm{b}}}=\underline{\text { between }}$ groups variance $=\underline{\mathrm{S}^{2}} \underline{\mathrm{B}}$

$$
\mathrm{V}_{\mathrm{w}} \quad \text { within groups variance } \quad \mathrm{S}^{2} \mathrm{~W}
$$

Where: $\quad \mathrm{V}_{\mathrm{B}}=\underline{\mathrm{SSB}}$, and $\mathrm{V}_{\mathrm{w}}=\underline{\mathrm{SSW}}$

$$
\mathrm{df}_{\mathrm{b}} \quad \mathrm{df}_{\mathrm{w}}
$$

Source: Ezejelue A. C., Ogwo E. O. and Nkamnebe A.D (2007) Basic principles in managing Research projects Aba-Nigeria-Afrotowers Limited Page 178

Based on the computation of figures on table 2, at 0.05 level of significance, the critical value of $\mathrm{f}=3.49$ (see table 2 ).

Since $\mathrm{f}>\mathrm{f} 0.05$ (3.49), the alternative hypothesis is accepted, hence the conclusion is that significance difference exists between the rating of the respondents on the impact of poor consumerism activities on the health and environmental standard in Nigeria.

Analysis is based on the analysis of analysis of variance (ANOVA) statistical tool; denoted by

$$
\begin{array}{rlll}
\mathrm{F}=\underline{\mathrm{V}}_{\mathrm{b}} & = & \underline{\text { between groups variance }}= & \underline{\mathrm{S}_{\mathrm{b}}} \\
\mathrm{V}_{\mathrm{w}} & = & \text { with groups variance } & \mathrm{S}_{\mathrm{w}}{ }^{2}
\end{array}
$$




\section{Macrothink}

Business and Management Horizons

ISSN 2326-0297

2013, Vol. 1, No. 2

Table 1. Respondents' rating of the impact of poor consumerism activities on the health and environmental standard of Nigeria

\begin{tabular}{|c|c|c|c|c|c|c|c|c|}
\hline \multirow{3}{*}{\multicolumn{4}{|c|}{$\begin{array}{l}\text { Value of product compared with price } \\
\text { Commitment to waste management by } \\
\text { manufacturers }\end{array}$}} & \multicolumn{2}{|c|}{ Manufacturing } & Intermediaries & \multicolumn{2}{|c|}{ Consumers } \\
\hline & & & & \multicolumn{2}{|l|}{240} & 60 & \multicolumn{2}{|l|}{50} \\
\hline & & & & 120 & & 40 & 30 & \\
\hline \multicolumn{4}{|c|}{ Level of market exploitation } & 30 & & 230 & 390 & \\
\hline \multicolumn{4}{|c|}{$\begin{array}{l}\text { Level of commitment to management } \\
\text { of waste }\end{array}$} & 50 & & 30 & 20 & \\
\hline \multicolumn{3}{|c|}{$\begin{array}{l}\text { Management of environmental } \\
\text { standard }\end{array}$} & & 120 & & 60 & 40 & \\
\hline \multicolumn{3}{|c|}{ Level of social responsibility } & & 140 & & 40 & 20 & \\
\hline \multicolumn{8}{|c|}{ Commitment to consumer welfare and } & \\
\hline \multicolumn{3}{|c|}{ Level of consumers protection } & & 60 & & 20 & 15 & \\
\hline \multicolumn{3}{|c|}{ Total } & & 870 & & 510 & 485 & \\
\hline \multicolumn{3}{|l|}{ Average } & & 124.2 & & 72.85 & 69.2 & \\
\hline \multicolumn{9}{|c|}{ Source: field survey 2013.} \\
\hline \multicolumn{9}{|c|}{ Table 2. Summary of ANOVA } \\
\hline $\begin{array}{l}\text { Source of } \\
\text { Variance }\end{array}$ & df & $\begin{array}{l}\text { Sum of } \\
\text { square (ss) }\end{array}$ & & $\begin{array}{l}\text { ean of } \\
\text { uare }(\mathrm{ms})\end{array}$ & $\mathrm{F}$ & $\begin{array}{ll}\text { Critical Sigr } \\
\text { value of } \mathrm{f}\end{array}$ & nificance & Decision \\
\hline $\begin{array}{l}\text { Between } \\
\text { groups }\end{array}$ & 2 & $\begin{array}{l}\mathrm{SSB}= \\
11545.21\end{array}$ & & $\begin{array}{l}= \\
72.61\end{array}$ & 0.749 & 3.49 & nificant & $\begin{array}{l}\text { Accept } \\
\mathrm{H}_{1}\end{array}$ \\
\hline $\begin{array}{l}\text { Within } \\
\text { groups }\end{array}$ & 18 & $\begin{array}{l}\mathrm{SSW}= \\
138,635.71\end{array}$ & & $\begin{array}{l}\mathrm{v}= \\
01.98\end{array}$ & & & & \\
\hline Total & 20 & $150,280.92$ & & & & & & \\
\hline
\end{tabular}


Table 3. Rating of variables that challenge the growth and development of consumerism in Nigeria

\begin{tabular}{llllll}
\hline Issues & Rating & & & \\
\cline { 2 - 5 } & 1 & 2 & 3 & 4 & 5 \\
\hline Poverty resulting from large income gap & $\circ$ & & & & \\
existing between the high and low & & & & & \\
income earners & & & & \\
Poor consumer education and awareness & $\circ$ & & \\
based on inadequacy in media & & & & \\
effectiveness & & & & \\
Lack of will power to enforce existing & & & & \\
consumerism abuse regulations & & & & \\
Poor market force (consumer) leadership & & & & \\
High level class consciousness among & $\circ$ & & & \\
Nigeria consumers & & &
\end{tabular}

Field Survey 2013.

Table 4. Rating of factors that spur up consumerism activities in Nigeria

\begin{tabular}{|c|c|c|c|c|c|}
\hline \multirow[t]{2}{*}{ Issues } & \multicolumn{5}{|c|}{ Rating } \\
\hline & 1 & 2 & 3 & 4 & 5 \\
\hline Consumer Education & & & & & $\circ$ \\
\hline Encouragement of consumer sovereignty & & & $\circ$ & & \\
\hline $\begin{array}{l}\text { Imposition of environmental protection } \\
\text { tax }\end{array}$ & & $\circ$ & & & \\
\hline $\begin{array}{l}\text { Pre and post production environmental } \\
\text { impact assessment }\end{array}$ & & $\circ$ & & & \\
\hline $\begin{array}{l}\text { Suasion of vendors to consumer oriented } \\
\text { policies and activities }\end{array}$ & $\circ$ & & & & \\
\hline Revocation of license of operation & $\circ$ & & & & \\
\hline De-regulation of economic activities & $\circ$ & & & & \\
\hline
\end{tabular}

Field Survey 2013.

\section{Interpretation of tables 3 and 4}

Scores: $\quad 1-2=$ High importance or impact

$3=$ moderate importance or impact

4-5 = low importance or impact 


\subsection{Remark and Interpretation of Hypothesis}

Drawing from the analysis of the hypothesis, the firms in the food and drink industries, their marketing intermediaries and the consumers are at variance in opinion on the assessment of the impact of poor consumerism activities on the health and environmental standard of Nigeria. While the firms' rate consumerism activity as well as health and environmental standard as high, the other respondents' rates are low. This variance in opinion counts for the littering of the environment with domestic and industrial wastes resulting from the consumption of the firms' products and their industrial operations.

\section{Findings and Discussions}

Some of the major findings of this work are:

- In the food and drink industries with market leaders as Nigerian Bottling Company Plc and 7up Bottling Company Plc-Non-alcoholic, and Nigeria Breweries Plc and Guinness Breweries Plc alcoholic; products are packaged in bottles, aluminum and plastic cans respectively. These respectively packaged products of these different firms have the same quality-ingredients, and are marketed based on the same logistics and promotion activities. However package sizes vary. This variation in size forms basis of price differences.

- It is important to note that bottled products of Nigerian Bottling Company Plc of $35 \mathrm{cl}$ are sold at consumer price of $\$ 60.00$ and those of 7Up Bottling Company Plc at $\$ 50.00$. These same product (NBC and 7Up) in aluminum can (package) of $33 \mathrm{cl}$ are sold for $\$ 100.00$.

- Based on the above, consumers pay higher for aluminum canned products of the food and drink industries compared to the bottled products. While $35 \mathrm{cl}$ content of the product is sold for $\$ 60.00$-bottled; $33 \mathrm{cl}$ of aluminum canned ought to be sold for $\$ 57.00$; but is sold at $\$ 100.00$. The producers charge consumers $\$ 43.00$ in excess.

- These products of the food and drinks industries like those of other industries are sold at high prices for the aluminum and plastic cans (packages) compared to the bottled products. This is even so when the bottles as residues of these products are subject to re-use through recycling. The benefits of re-use of the bottles to the producers should have been reflected in lower price for aluminum and plastic canned products as the consumers of aluminum and plastic canned products are expected to bear the burden of packaged disposal. Based on the fore-gone the high prices of products with disposable package are unfair to the consumers.

- Research results show that the producers of food and drinks products like all others in pharmaceutical industry, are not committed to improving the environmental standard of Nigeria, hence their disposable packages as residue are allowed to litter the physical environment, block the drainage system and constitute heaps of refuse in major and minor streets of the towns and villages. Consumers during organized and unorganized sanitation periods are expected to carry away these refuse at their cost. Research results have it that shifting the incidence of the management of the residues (waste) to the consumers or government is dis-service to the consumers. 
- Based on the analysis, it is right to put on records that producers, as market force in Nigeria, especially those in the food and drink industries are exploiting the consumers, and are debasing the environment as their aluminum and plastic packages as wastes litter the environment. These practices of the producers are not marketing concept oriented thus they are de-marketing based and are socially irresponsible.

These activities of Nigerian firms, if exhibited in the developed economies are sufficient to evoke consumer (consumerism activities) reactions.

Table 3 asserts that the main cause of the inactive nature of consumerism in Nigeria are, poverty among consumers given the low per capita income, poor level of consumer education and consequent poor market force (consumer) leadership and high level of consumer consciousness, while lack of will power of government to enforce existing regulatory plays supportive role.

Table 4 shows that the effective fight against of consumer rights abuse in Nigeria anchors on government activities on de-regulation of the economy, suasion of vendors to consumer oriented policies and activities, imposition of environmental protection tax, pre-and-post production environmental impact assessment and revocation of licence of corporate operations.

Analyses on tables 3 and 4 show that consumers activities as effort at protecting and enforcing consumer right in Nigeria will not yield desired result without government playing active role, as Nigeria consumers are dossal and inactive, having no focus.

Reasons for the low level of consumerism activities in Nigeria based on the research evaluation that followed the Likert statistical (model) tool. See table 3 (three) include:

\section{- Absence of Competition}

The food and drink industries represented by bottling and brewery industries in Nigeria are dominated by few multi-national companies like the pharmaceutical and tobacco industries. The situation is such that demand is greater than supply especially as market leaders adopt various pricing strategies aimed at eliminating competition. Given this situation of excess demand over supply, consumers rather than complain about quality and prices pay higher price for $33 \mathrm{cl}$ coke in aluminum and or plastic can compared to $35 \mathrm{cl}$ in the bottle. This is not only in the bottling industry as it is obtainable in the automobile, detergent and soap industries-Agbonifoh, Ogwo, Nnolim and Nkamnebe (2007:663). The situation in Nigeria shows that consumers are not only threatened by the concentration of economic power in small number of firms, but also by the failure in many cases by the regulatory bodies to exercise check on the negative competitive activities of the firms-Gill (1975:592), NAFDAC (2008) and Ayozie (2013). In the banking and telecommunication industries where business activities are reasonably de-regulated, consumers are beginning to receive value in exchange.

\section{- Unbalanced Purchasing Attitude of Nigerians}

Consumers of the products of these firms in Nigeria are likely to continue in their loyalty, as 
their attitude and perception as well as evaluative criteria are influenced given the continued promotion of these products. These consumers exhibit the fact of selective rejection of information about the environmental impact of residues (aluminum and plastics) generated given the consumption of products of these bottling companies, hence the abuse of their sovereignty by these firms.

The abuse is compounded given the fact that Nigeria consumers are emotionally motivated in purchases, buying out of fear of being looked upon as poor; comfort, affection, curiosity or fashion- Ifezue (1989) and naturalnigeria.com/2012. This accounts for why consumers will not take time to consider that the bottling companies given the reverse logistics in the bottle residues are exploiting the market and debasing the environment using aluminum cans and plastic packages.

Nigerians generally are not skillful nor intelligent buyers; they do not obtain maximum value for the money spent, neither do they know what they want and how much they are willing to spend for it-Hopkin 91979:374) and etukudo (2008). This suggests why Nigeria consumers do not wait to find products that offer value. This attitude of the Nigeria consumers does not encourage consumerism activity.

\section{- Low level of awareness and consciousness}

Authorities in marketing argue that the general low level of literacy is responsible for the low level of consumerism activities in Nigeria-Agbonifoh, Ogwo, Nnolim and Nkamnebe (2007:663), naturalnigeria.com/2012, etukudo (2008), Halliru (2012) and Ayozie (2013). The preliminary research result on this work attributes the situation more to low level of awareness. Consumers are not aware that the bottling and brewery firms are exploiting them in terms of product quantity-aluminum /plastic package vis-a-vis bottle package, price of the product and the impact of the aluminum/plastic packages as waste on the environment. Because consumers are unable to judge product quality, they do not know their rights as consumers-Agbonifoh, Ogwo, Nnolim and Nkamnebe (2007:663). The few who are aware especially in the East and Northern parts of Nigeria consider litigation a waste of money and time-Halliru (2008) and Ayozie (2013). In the Western region consumers show apathy to reporting the violation of their rights to appropriate authorities - Adrika, Ebue and Nnolim (2001:300). Consumerism activities may not be ignited in Nigeria as consumers are not aware that their right to good environment is violated-Ayozie (2013), especially as they have not perceived the health and safety problems accompanying the activities of the firms in the bottling and brewery industries - Onah (1979: 132).

\section{- High Level of Poverty}

The economic situation in Nigeria has eliminated the middle class income earners. In existence currently are the mass low income earners and the few high income earners. This situation of income disparity does not encourage consumerism activities. The mass poverty situation constraints the ability of the citizens to initiate and sustain fights against the abuse of their rights by producers and vendors especially in the food and beverage industries-Agbonifoh, Ogwo, Nnolim and Nkamnebe (2007:663), Ayozie (2013), Halliru 
(2012) and Ijewere and Obeki (2011). This is because the few that have the money, do not have alternative products to buy as a means of influencing the activities of firms that violate their health, safety and environmental standards-Hopkins (1979:375).

\section{- $\quad$ Absence of Good Quality Leadership}

The middle class income (earners) group does not exist in Nigeria-Akerele (1980:44-51) and Ijewere and Obeki (2011), hence able, selfless and fearless leadership required to spur up consumerism activities is absent. The upper class people constitute major investors in these corporate bodies that exploit the market and the physical environments, thus do not have the courage to fight their investments and sources of profit.

\section{- $\quad$ Lopsided Media Activities}

Media activities in Nigeria are on the basis of "he who pays the piper dictates the tone" the business community with its economic power has always dominated and exploited the weaker market force-consumers. Most adverts are aimed at promoting the profit course of business —etukudo (2008) and naturalnigeria.com/2012.

Firms in the food, beverage and tobacco industries as well as those in the bottling and brewery industries have always employed the services of the media in sales promotion and general advertisement for turn-over enhancement but have not made any deliberate efforts at educating the market on their product end-user waste management neither do they discuss the environmental implications of poor product residues management hence, the major and minor towns in Nigeria have heaps of package wastes in aluminum and plastic cans. Media alertness and fearlessness especially given the poor waste management activities of the multi-nationals in the bottling, brewery, food and beverage industries can help educate consumers and check the excesses of businesses-Agbonifoh, Ogwo, Nnolim and Nkamnebe (2007:664). This weak position of consumers and consumerism activities in Nigeria is attributed to the absence of independent media, especially as the available media services are not responsive journalism oriented, hence malpractices of businesses are not given adequate exposure, suffering of consumers given environmental debasement and economic power exploitation are not highlighted, neither are the consumers educated on appropriate means of seeking redress as businesses neglect and abuse their rights. Contrary to this, the media deceives the consumers, hence the market have lost faith in the ability alone to protect itself-Edoreh (2007), the controltower.blogspot.com/2008 and Halliru (2012).

\section{- $\quad$ Lack of Governmental Commitment:}

Governments in Nigeria have not been, neither have they shown sufficient degree of responsiveness to consumer protection-Agbonifoh, Ogwo, Nnolim and Nkamnebe (2007). Laws, regulations and protocols on consumer protection are passed, en-acted and ratified by governments but are not sufficiently enforced-Okpara (2002:546), Halliru (2012), Ayozie (2013) and etukudo (2008). This lack of government commitment is attributed to lack of skilled personnel but majorly, it is that of absence of morally stable personnel as greater number of these personnel swim in bribery and corruption-Adirika, Ebue and Nnolim (2000:309). Worrisome also is the meld punishment considered to be lenient to have any 
impact on natural and artificial persons that abuse the rights of consumers. Given the above, the public would be interested in knowing government reaction to the report credited to the Department of Petroleum Resources (2009), Adewakun and Sheu (2013) and Ijewere and Obaki (2011), that many oil marketers in Nigeria were found to have tempered with their pump, dispensing lower value of Premium Motor Spirit (PMS) to their customers. Hence customers lose 1.2 litres of PMS in every 10 litres of the product bought in Conoil, 0.8 litres in Onado and 0.6 litres in Texaco.

\section{Implications of Findings}

Based on the findings of this work, the implication is that majority of the citizens of Nigeria considered consumers of the products of the food, beverages, bottling, and brewery industries will continue to be exploited explicitly and implicitly by the concerned firms.

Explicit exploilation relates to the high price of the product especially given the content of the bottled products compared with the aluminum and plastic canned products. The re-cycling and the re-use of the bottles as end users waste (residues) at no logistics cost to the producers makes the bottled products relatively more cost effective in favour of the producers.

Implicitly, the firms in these industries exploit the consumers and non consumers as the physical environment of the Nigeria populace is littered with empty aluminum and plastic cans as residues. These residues block drainage systems, debase the earth surface, and pollute the air and basic sources of domestic water. These in aggregate constitute environmental nuisance and a breach of corporate environmental and social responsibility, duties as the hygiene and health standard of the nation's major and minor towns are negatively affected.

In major towns where government of states and municipal councils show interest in ensuring evacuation of domestic and industrial wastes as occasioned by the activities of these producers, it is done at cost to government, and developmental investments are considered opportunity costs, which the citizens are made to bear.

Given the cost implication of breaking the near-monopolistic nature (structure) of the firms in the food, beverage, bottling and brewery industries based on direct public sector participation especially as most firms in the industries are operating at the level of economy of scale and increasing returns to scale principle, it is near impossible for real competition to be practiced in these industries. Based on this premise, the Nigeria consumers will continue to be exploited; hence solution to poverty may remain elusive.

The general call therefore is to awaken the consciousness of consumers as a means of igniting consumerism activities in Nigeria.

The firms in the food, beverage and tobacco industries as well as those in the bottling and brewery industries lack the courage to educate the consumers on basic choice of product alternatives for fear of depleting the market for the aluminum and plastic canned product-main source of profit generation, rather they promote activities in this area highlighting "convenience and prestige". This unbalanced education (quantitative rather 
than qualitative) is exploilative; generating consumer information gap-Adirika, Ebue and Nnolim (2001:301) and naturalnigeria.com/2012.

The study of consumerism in Nigeria shows that the fight against consumer rights abuses and exploitations by businesses is yet to commence - etukudo (2008), naturalnigeria.com (2012) and Adewakun and Shue (2013).

\section{Conclusion}

Catalyzing consumerism activities in Nigeria may not be an easy task, as consumers themselves lack the will power to take action. Causes of this inactive nature of the movement are majorly attributed to the existing high level of poverty among consumers, resulting to poor market force leadership and high level of class consciousness among consumers, hence the fight must be fought from the OMBUDSMAN stand point, as government is expected to persuade vendors to quality market offer, imposition of environmental protection tax and execute pre-and post efficient and effective product manufacturing impact assessment, in addition to the introduction of policies of de-regulation of the economy.

\section{Recommendations:}

Consumerism is not properly developed in Nigeria-Onah (1979), Halliru (2012) and etukudo (2008). This assertion is still relevant after over 28 (Twenty eight) years it was made, hence Agbonifoh, Ogwo, Nnolim and Nkamnebe (2007:664) assert that improving the welfare of consumers in Nigeria is a real area of need that has been neglected by politicians, political parties, governments, business organizations, and above all, consumers. This latter statement confirms the expressed governmental inertia-Okpara (2002:546) in consumer protection.

The fight against consumers' rights abuses is yet to achieve desired results especially considering the present plight of consumers. Following the assertions of marketing authorities cited by Adirika, Ebue and Nnolim (2001: 300) thus:

...consumers' rights have been ignored in what might be referred to as a sellers' market in Nigeria-Nwokoya 1981...the poor consumer is treated like an orphan before his birth-Uche (1980).

There is an in-balance in the power relations between consumers and producers of goods and services; especially as consumers lack knowledge of the characteristics and technical components of market offers. The superior bargaining power of the vendors over consumers and the fact that vendors are more endowed in terms of resources make the consumers weaker in this power relations-CPC (2010) and Halliru (2012). The situation of the consumers makes the role of government imperative in consumer protection.

It is a shared opinion that governments have made some efforts aimed at protecting consumers through various legislations and the establishment of consumer protection agencies such as Consumer Protection Council and National Agency for Food and Drugs Administration and Control. The administration of these laws and bodies has generally been 
ineffective-Agbonifoh, Ogwo, Nnolim and Nkamnebe (2007:664), etukudo (2008) Halliru (2012), Ijewere and Obeki (2011). Hence the protection of consumers' right lays squarely on the consumers themselves. It is therefore important that consumers should be educated and informed on business practices that constitute violation of their rights - naturalnigeria.com/2012, www.globalissues (2012) http:/en.wik,pedia.org/wiki/consumerism and Kaynak (1982). The violation must however be "adequate" to aggrieve consumers to seek redress.

Suggestions that business organizations whose practice are not marketing concept oriented should establish units of consumer affairs, change corporate practices which consumers consider deceptive and or antagonistic and encourage channel members to be corporate consumerism policies oriented-Burskirt and Rothe (1970:61-65), and or the incorporation of the increased costs of consumerism efforts into corporate operating budget-Kotler (1972:48-57) may not achieve desired results in Nigeria as corporate objectives of businesses are influenced by top management/managers' philosophy. These philosophies in Nigeria are not consumer welfare oriented, thus most Nigeria consumers are frustrated. To this end, this work shares the opinion of Herrman (1970:55-56), that frustration affecting many people in the population is not sufficient for the development of consumerism; as consumerism strives when activist as opine Chandon and Strazziert (1980:17) are characterized thus:

More satisfied than others in their living conditions, as much as well integrated within the society, more attracted by novelty, more willful, self asserting and articulated and more discontented by advertising practices and their supposed pervasiveness...

Such activists in addition must have vision of better state of affairs and the prospects of attaining it and must give leadership to the attainment of the goals of consumerism movement - Herrman (1970:55-56). These leaders are not, rather are few in Nigeria given the extinction of the middle class income earners. Absence of consumer activists affirms the truth of the fact that protection of consumers right lays squarely in the consumers themselves.

Following the poor practice of consumerism in Nigeria especially in the absence of enabling environments, this work recommends the following as fallouts of the Likert scale rating of variables that spur up major stakeholders in consumerism movement in Nigeria-see table 4 (four).

\section{- Judicious Use of Consumer Sovereignty:}

Benefits are accruable to consumers, the business organizations and the society as the consumers are judicious in the use of their sovereignty. These benefits are: the buyers as consumers are considered skillful, as such they receive maximum value for their money; sellers are encourage to be responsiveness to the needs of the consumers and good business practices are encouraged-Hopkin (1979:374), www.globalissues.org (2013) and naturalnigeria.com/2012 
In Nigeria, especially given the activities of the firms in the food and drink industries, buying the bottled products only (whose wastes (residues) are subject to re-cycle and re-use based on reverse logistic management) will discourage the production of the aluminum and plastic canned products, hence the negative impact of wastes associated with aluminum and plastic cans will be avoided.

This is put by Hopkin (1979:375) thus:

Buy goods and services form honest sellers, in refusing to support dishonest practices; skillful consumers prevent these firms from making profits. Skillful consumers can also influence the activities of firms that violate health, safety and environmental standards.

The maximization of the benefits of judicious use of consumer sovereignty can only be achieved given quality consumer education and effective management of consumer buying behaviour based on the management of consumer's emotion and buying motivation variables-naturalnigeria.com/2012. Desire to buy items based on fears and insecurities should be discouraged in Nigeria consumers, rather the principles of minimalism should be encouraged-Leo (2013).

\section{- Imposition of Environmental Protection Tax}

The government at various levels of authority may take over part of organizations' corporate social responsibilities to the consumers; vis-à-vis the physical environment at cost to the firms rather than the consumers. To this effect, this work recommends the imposition of environmental protection tax; collectable at the National Corporate Headquarters of the different organizations periodically. Accruable from these taxes will cushion the cost of environmental protection and waste disposal management, among the different tiers of government.

It is important to note that this recommendation has challenges; among these is lack of government accountability as it is in the case of value added tax; attitude of officials of the tax system like those of the different price control boards leaves much to be desired as they swim in bribery and corruption-Adirika, Ebue and Nnolim 2001: 309) and Ayozie (2013).

\section{- Pre-and Post Production Environmental Impact Assessment}

Government through her agencies in the Ministry of Environment especially those on environmental protections should lead producers and possibly execute the product impact assessment of organizations' offer with special interest in waste and its management. This should be a pre-requisite for licensing the organizations to production and marketing. This impact assessment should be repeated periodically after commencement of operation for possible variance analysis and control of the consequences of poor waste management. This if implemented in Nigeria will call firms in the food and drinks industries to order in respect of the impact of their operations and product and users (domestic) residues on the environment. 


\section{- Mobile Authentication Service(MAS)}

As part of government efforts at protecting consumers, the National Agency for Food and Drug Administration and Control-NAFDAC has deviced anti-counterfeiting solution technology; a device that enables the Nigeria consumer verify the originality or otherwise of market offers in the Pharmaceutical industry. This device has a rapid response rate, hence authenticity of drugs are ascertained at the point of purchase.

Mobile Authentication Service provides a silvery portion on the product that when peeled off reveals a set of numbers short code 38353 through which the quality of the drug will be ascertained based of free SMS-Adekanmbi (2012). The Mobile Authentication Service is mandatory for all Pharmaceutical firms with effect from January 2013.

This research is of the opinion that the MAS device will aid the curbing of production and marketing of poor quality products in the Pharmaceutical industry and serve as a qualitative consumerism effort. However, the low level of literacy and the high incidence of poverty among Nigerians are considered challenges to the effectiveness of the device.

\section{- Revocation of License of Operation}

Government in extreme cases of environment responsibility violation could revoke the license of operation of firms. This will help caution other firms concerning their activities.

\section{- Suasion Rather than Directive}

Businesses rather than build on product selling concepts anchored on making more sells, more stuff to more people more often for more money in order to make more profit - Newman (1999) and Newman (1999), should be persuaded to accept the marketing concept philosophy. The philosophy that directs the actualization of corporate goal through consumer satisfaction-Berkowitz, Kerin, Hartley and Rudelius (2000), for both the short and long term operations. Nigeria business orientation like the developed economic should not stress on finding the right customers for corporate offer rather to find the right products for the target market-Kotler and Keller (2009). Firms should be discouraged from considering competition as intra industrial only, rather it is inter and intra industrial and generic, hence the fewness of firms in the food and drink industries and the strive to destroy competition through collusive oligopoly-Oko (2002) is a dis-service to the economy. The generic nature of competition gives credence to marketing concept as key to achieving organizational goals through being more effective than other firms (inter and intra industrial) in creating, delivering and communicating superior customer value to identified and defined target market (s) - Kotler and Keller (2009). Customer focus and value should be considered paths to sales and profits-Kotler and Armstrong (2006). The adoption of marketing concept in the different sectors of the economy inclusive of the food and drink industries has the potential to redressing the unbecoming in business practices, reducing the level of consumer dissatisfaction and promoting their satisfaction-Okeke (1981), as well as enhancing the health and environmental standards of Nigeria. 


\section{- De-regulation of Economic Activities}

Interviews with stakeholders in the fight against abuse of consumers rights as individuals and corporate personalities, advocate for de-regulation of the Nigerian economy. The government of Nigeria as a least cost alternative (option) to controlling abuse of rights of consumers should like in many other countries de-regulation different sectors of the economy. This will create greater competition and generate employment opportunities-Kolter and Keller (2009), as small businesses will spring up, and strongholds of major (large scales) businesses will be broken and the predatory behaviour of businesses will be put to check-Bateman and Snell (1999). The developments in the banking and telecommunication industries in Nigeria attest to the fact that de-regulation policies are useful for consumer protection.

\section{References}

Abubakar, M. (2010). Nigeria Among Nine Most Illiterate Countries in the World. Retrieved August 2, 2011, from www.nairaland.com/nigeria topic/illiterate countries.

Adeknmbi, D. (2012). Mobile Authentication Service Nigeria Tribune.

Adewakun, A., \& Shue, B. (2013). Apathy, Weak Legislation, Major Disincentives to consumerism in Nigeria-Stakeholders. Retrieved from www.tribune.com.ng/.../7854-apathy-weak-legislation-major-disincentives

Adinoyi-Ojo, Onukaba, Ogunseitan, Sun, O. J., Ogberide, E., \& Anukwe, O. (1988). Worrying Cracks in Medical Practice. The Guardian, Saturday September 18.

Adirika, E. O., Ebue, B. C., \& Nnolim, D. A. (2001). Principles and Practices of Marketing (12nd ed.). Enugu, Nigeria: John Jacob’s Classic Publishers Ltd.

Agbonifoh, B. A., Ogwo, E. O., Nnolim, D. A., \& Nkamnebe, A. D. (2007). Marketing in Nigeria Concepts, Principles and Decision (2nd ed.). Aba, Nigeria: Afritowers Limited.

Aire, J. U. (1974). Consumer Attitudes to Made-In-Nigeria Goods and the Implications for Marketing. Management in Nigeria.

Akerele, B. (1980). The Relevance of Consumerism for a Developing Economy. Nigeria Journal of Marketing, 2(December).

Ayozie, D. O. (2013). Consumerism the Shame of Marketing in Nigeria: Challenges to Corporate Practices. Universal Journal of Management and Social Sciences, 3(3).

Berkowitz, E. N., Kerin, R. A., Hartley, S. W., \& Rudelius, W. (2000). Marketing (6th ed.). New York: Irwin McGraw Hill.

Burskirk, R., \& Rothe, J. T. (1970). Consumerism: An Interpretation. Journal of Marketing, October

Chandon, J. L., \& Strazzleri, A. (1980). Who Are the European Consumerists. Paper Presented at the Joint Meeting and Conference, Edinburgh. March 25-28.

Cohen, D. (1991). Trade Mark Strategy Revisited. Journal of Marketing, July. 
http://dx.doi.org/10.2307/1252147

Edoreh, E. (1984). Consumer Protection: A Study of Consumers' Awareness of their Rights and Complaining Behaviour in Benin City. An Unpublished MBA Thesis June.

Etukudo. (2008). Advertising and Consumerism in Nigeria. The Control Tower. Retrieved from thecontroltower.blogspot.com/.../advertising-and-consumerism-in -nigeria

Ezejelue, A. C., Ogwo, E. O., \& Nkamnebe, A. D. (2008). Basic Principles in Managing Research Projects (2nd ed.). Aba, Nigeria: Afritowers Limited.

Gill, R. T. (1973). Economics: A Text with Included Readings. California Gold Year Publishing Company Inc.

Halliru, M. (2012). The Development of Consumerism in Nigeria: Prospects and Challenges. International Journal of Arts and Commerce, 1(4).

Heckman, J. (1999). Laws that take Effect and Some likely to Return-in 1999 Mean Marketers Must Change Some Policies. Marketing News.

Herrman, R. O. (1970). Consumerism: Its Goals, Organisation and Futru. Journal of Marketing, October. http://dx.doi.org/10.2307/1250712

Hopkins, C. (1979). General Business in Modern Society. Canada Glen Loe Inc.

Ifezue, A. N. (1989). Buying Motives and Habit of Consumers. Foundation of Business Administration ed ita Ejiofor, Onitsha, African Fap.

Ijewere, A. A., \& Obeki, S. O. (2011). Consumerism in Nigeria. JORINO, 9(2).

Jakata. (2004). Consumerism. Wikipedia. Retrieved from https://en.wikipedia.org/wiki/consumerism.

Kaynak, E. (1982). Marketing in the Third World. New York: Praeger.

Kaynak, E. (1985). Some Thoughts on Consumerism in Development and Less Developed Countries. International Marketing Review, 2. http://dx.doi.org/10.1108/eb008273

Kotler, P. (1972). What Consumerism Means for Marketers. Harvard Business Review, May-June

Kotler, P., \& Keller, K. L. (2009). Marketing Management (13rd ed.). London: Pearson Education Limited.

Kotler; P., \& Armstrong, G. (2006). Principles of Marketing (11th ed.). New Jersey Pearson Education, Inc.

Lawson, A. O. (1977). Company Institution Against The Weakness of Employees. Management in Nigeria, 13(3).

Leo. (2013). Consumerism Vs Minimalism: Retrieved from mnmlist.com/consumerism-vs-minimalism-29/06/2013 
Nafdac. (2003). Battle against Fake Drugs. Retrieved from http://www.nafdacnigeria.org

Nafdac. (2005). Achievement. Retrieved from http://www.nafdacnigeria.org

Natural Nigerian. (2012). Are Nigerian Caught Up in Consuerism? In Saopbox. Retrieved from naturalnigeria.com/2012/04/are-nigerians-caught-up-in-consumerism.

Newman B. I. (1999b). The Mass Marketing of Politics. Thousand Oaks, CA: Sage Publications.

Newman, B. I. (1999a). Handbook of Political Marketing. Thousand Oaks, CA: Sage Publications.

Ogbide, M. (1981). Smuggling: Nigeria’s Growth Industry. National Concord February.

Oghuma, A., Arinze, D., \& Mba, J. (1988). NITEL'S IDD Battle: Victoria Island Residents Kick as NITEL Forces on IDD on Them. Newswatch, September 26.

Ogwo, E. O. (1999). Perspective in Nigerian Marketing-Aba-Martha Israel.

Okeke, C. I. (1991). "Consumerism in Nigeria” The Case for an Ombudsman. In Ogwo, E. O. (Ed.), Aba Perspectives in Nigeria Marketing. Martha Israel.

Oko, A. E. N. (2002). Economic Premises for Business Decisions. Enugu-Nigeria John Jacob's Classic Publishers.

Okpara, G. S. (2002). Contemporary Marketing Topical and Tropicalized. Enugu-Nigeria: John Jacob's Classic Publishers Limited.

Oloke, A. (1988). The Influence OF Marketing on Consumers in a Production Oriented Economy: A Case Study of Consumers. In Okigwe and Owerri B.Sc Project Report Imo State University Okigwe. August.

Olusoga, S. A. (1978). The Marketing Concept in a Developing Economy-A Critical Appraisal. Nigeria Journal of Business Management, July/August.

Omenazu, P. (2010). Consumer Protection in Nigeria. Retrieved August 4, 2011, from $\mathrm{http} / /$ trifter.com/africa/ nigeria/consumer-protection in -nigeria

Onah, J. (1979). Consumerism in Nigeria. Marketing in Nigeria. London: Cassel.

Orere, O. (1988). New Malaria Policy May Spara Masquitoes. The Guardian, Tuesday August 9.

Osunbor, O. O. (1984). Fraud and Insurance Contract. Business Times, March, 12.

Otu, M. (1988). A Dog That Watches. Newswatch, May 16.

Roger, B. (2009). Fighting Fake Drugs. The New Altentis, Summer, 107-112.

Sanwo, P. (1975). The Exhibition of Made-In-Nigeria Goods. NBC Newstalk, July 15.

Standard Organisation of Nigeria. (2003). Historical Background of SON. Retrieved from 
http://www.sononline.ng.org

Standard Organisation of Nigeria. (2006). Functions, Goals and Structure of SON. Retrieved from http://www.nigeriafirst.org

\section{Copyright Disclaimer}

Copyright reserved by the author(s).

This article is an open-access article distributed under the terms and conditions of the Creative Commons Attribution license (http://creativecommons.org/licenses/by/3.0/). 